\title{
ICT and Agriculture Development A Farm Level Case of Nepal
}

\author{
Meera Gautam \\ Lecturer, Shanker Dev Campus, Faculty of Management, Tribhuvan University \\ Nepal \\ Email: krishikrg [AT] gmail.com
}

\begin{abstract}
The main objective of this research is to assess the status of satisfaction level of ICT use for knowledge gain and skill adoption on Agriculture Information need and its use for sustainable agriculture transformation towards derivation of market. For this purpose Dhaitar Bhanjhang Mahadevsthan 2 Mmahadevsthan and Patlekhet-8 Kalchebesi VDC's of Kavrepalanchowk out of seventy seven districts is selected. Information's were collected from a purposive sample of 98 farmers during January 2017. Four methods were used in the process of finalizing data collection instruments. Information were collected through four tools face-to-face interview by using personal interview schedule, Focus Group Discussion (FGD), key-informant interview (KII) and consultation with experts from public and NGO sector extension service providers, A sample 98 was purposively selected due to the nature of research. Likert scales were developed and used in order to measure the concerned variables. Correlation test was used to ascertain the relationships between the concerned variables. More than one third (37.3 percent) of the farmers were found to use mobile phones for receiving agricultural information, while 21.3 percent used internet facilities provided by national and international web media. Only 2 percent farmers were found having use of smart phone. The use of ICT is used mainly in the case of market derived vegetable production and its prices at different market.
\end{abstract}

Keywords--- Satisfaction level of ICT, Knowledge, skill, Market derived, Kavrepalanchowk

\section{INTRODUCTION}

Information and Communication Technologies (ICT) has become an integral part of all spheres of life in today's world. Farming involves risks and uncertainties due to geography; climate, raw materials required and ICT can deliver useful information to farmers on crop care, fertilizers, seed resource, and market price. ICT can make a significant contribution in productivity and sustainability of small scale farmers. ICTs are now being used in agriculture for receiving various information such as market price of products, various improved technologies, and solution of various problems faces in agriculture production. ICT tools can be used to find, explore, analyse, exchange and present information responsibly and without discrimination. ICT can be employed to give users quick access to ideas and experiences from a wide range of people, communities and cultures.

In Nepal about $65.5 \%$ population is involved in agriculture for their livelihood (MoLMAC,2015) and is contributing nearly 33\% in Gross Domestic product (MoF, 2018). Besides this agriculture sector is the second biggest export sector next to industry in the country (TEPC, 2015). The man land ratio is increasing and is reached to 10.5 in 2011 compared to 5.6 in 1961 (CBS, 2014). The farm size is 0.7 ha per holding. In this situation this sector's progress and stagnation play a major in Nepal's overall economic growth.

Nepal has pluralistic agriculture extension services. In addition to Department of Agriculture and Department of Livestock under Ministry of Agriculture Development (MoAD), many INGOs and NGOs offer education and training to farmers. Public Extension workers (9496) at the ratio of 1:1580 households in the case of crop and fisheries, in livestock it is 1:1906 households. At organizational level the nearest extension providers is Agriculture (ASC) and Livestock Service and Sub- Service Centers (LSSC) the ratio per ASC (378) is 1:11396 and at LSSC (999) it is 1:4312 (MOAD, 2071 BS).Thus, they are trying to serve 3831093 households (CBS 2013). 
The publically provided extension services through group leader, regular time bound radio and TV programmes are technology delivery means for enhancing crop diversification, cropping intensity and productivity of the agriculture resources. In this regard through group leaders farmers were supported through demonstration, mini kit distribution, farmer's group formation, farmer's tour and agriculture fair organization. This service has served nearly $18-20 \%$ of farming $\mathrm{HH}$ and those who have received the services have improvement in the production system (AED 2017). But the service support through group leader coverage is limited due to various factors. In this context coverage of technical knowledge and skill disseminations approach and tools may be needed and use of ICT is observed an effective tools (World Bank 2011).

Enhancing the ability of smallholders to connect with the knowledge, networks, and institutions necessary to improve their productivity, food security, and employment opportunities is a fundamental development challenge. Where once rural areas were largely disconnected from the greater world, today, networks of information and communication technologies (ICTs) enmesh the globe and represent a transformational opportunity for rural populations, both as producers and consumers.

It could be easily understood from the above facts and discussions that technical knowledge and skill delivery tools used by the farming community needs to be assessed in the context of market driven product production in Nepal. It is necessary to make a proper understanding of actual field level situation of ICT use as well as its impact in farmers in receiving agricultural information. To increase the extent of use of ICT based media in receiving agricultural information, it is necessary to have a clear understanding about present status of use of ICT based media by the farmers and it's associated challenges. There is a dearth of research based information in this much needed field.

Given the challenges, the arrival of information communication technology (ICT) is well timed. The benefits of the green revolution greatly improved agricultural productivity. However, there is a demonstrable need for a new revolution that will bring lower prices for consumers (through reduced waste and more-efficient supply chain management), contribute to "smart" agriculture, and incentivize farmers (for example, through higher income) to increase their production. Public and private sector actors have long been on the search for effective solutions to address both the long- and short-term challenges in agriculture, including how to answer the abundant information needs of farmers. ICT is one of these solutions, and has recently unleashed incredible potential to improve agriculture in developing countries specifically. Technology has taken an enormous leap beyond the costly, bulky, energy-consuming equipment once available to the very few to store and analyze agricultural and scientific data. With the booming mobile, wireless, and Internet industries, ICT has found a foothold even in poor smallholder farms and in their activities. The ability of ICTs to bring refreshed momentum to agriculture appears even more compelling in light of rising investments in agricultural research, the private sector's strong interest in the development and spread of ICTs, and the upsurge of organizations committed to the agricultural development agenda (World Bank 2011).

The present paper focuses on the following specific objectives: (i) determining the nature and extent of use of ICT based information by the farmers for receiving agricultural information; (ii) describing socio-economic characteristics of the internet and mobile phone user farmers; and (iii) identifying effectiveness of the its use.

\section{METHODOLOGY}

The study was conducted in two VDC's (Village development Committee) within Kavrepalanchowk District of Nepal. The VDC's were selected purposively on the basis of information from DADO (District Agriculture Development Office) where farmers are using ICT based information and NGO (Non governmental Organization ) with the support of International Non Governmental Organization (INGO) piloting the ICT based information delivery system. In consultation with the Agriculture Service Center (ASC) and local level service providers from NGO.

The population of the study included the farmers of the selected villages farming community with the assess of ICT based information. An updated list of farmers who were active in technology use was collected from the NGO facilitator. All 196 targeted members of the farmers were listed out and from that list only $75 \%$ of farmers were selected for the study purpose. Therefore, the sample size for data collection stood to 98 Farmers.

After reviewing the available published literature a scientific and systematic procedure was developed and adopted for conducting the investigation following survey methodology (Kothari, 2007). Four methods were used in the process of finalizing data collection instruments. These were face-to-face interview by using 
personal interview schedule, Focus Group Discussion (FGD), key-informant interview (KII) and consultation with experts. This paper is based on the secondary as well as primary information published from governmental organization and from the selected Communities' of Kavrepolanchowk district. The community Dhaitar Bhanjhang Mahadevsthan 2 Mmahadevsthan and Patlekhet-8 Kalchebesi- Kavrepalanchowk The information was collected with the use of Likert scaling approach. The collected information was analyzed using Excel spread sheet and Likert scale of 5 where 1 indicated not effective and 5 indicated very effective.. The information is interpreted simple in percentage and mean value.

\section{RESULTS AND DISCUSSION}

\section{Status of Sampled VDC with population and having different facilities:}

In sampled Kavrepalanchowk district the total number of Village Development Committees (VDC) number are 90, now called Palika's and their number is 13 with a population of 381937. The sampled VDC's households are 1549 in Kushadevi with total population of 7114, average family size 4.59 members and male fenale ratio of 84.78 in the same way in Mahadevsthan Mandan households of 1873 , population of 8166, family size of 4.36 and sex ratio of 09.97 Table-1.

Table 1Number of Households in sampled VDCs

\begin{tabular}{|c|c|c|c|c|c|c|}
\hline \multirow{2}{*}{ V.D.C. } & \multirow{2}{*}{ Household } & \multicolumn{3}{|c|}{ Population } & \multirow{2}{*}{$\begin{array}{c}\text { Average } \\
\text { Household Size }\end{array}$} & \multirow{2}{*}{ Sex Ratio } \\
\hline & & Total & Male & Female & & \\
\hline Kushadevi & 1,549 & 7,114 & 3,264 & 3,850 & 4.59 & 84.78 \\
\hline Mahadevsthan Mandan & 1,873 & 8,166 & 3,890 & 4,276 & 4.36 & 90.97 \\
\hline
\end{tabular}

\section{Source CBS, 2012}

There are four technical sections, in DADO Kavrepalanchowk which is public sector agency for technological skill and knowledge dissemination responsibility for the sampled district VDC's, which are Planning, Plant Protection, Agricultural Extension and Horticulture Development sections. Agriculture development program are run in all 89 VDCs of Kavrepalanchowk, six agricultural service centers and in few of pocket areas at the grass root levels. The supervision and technical backstopping in the VDC level are done through 6 Agriculture Service Centers each for agriculture and in the district level are done through one head office, DADO. The research project identified pocket areas scattered in 2 VDCs identified. The main economic activity is agriculture where more than 85 percent population are engaged.(DADO 2017). The literacy status in these two VDC is 74.11 in Kushadevi and 68.23 in Mahadevsthan Mandan percent (CBS, 2012)

Figure 1 Household having facility

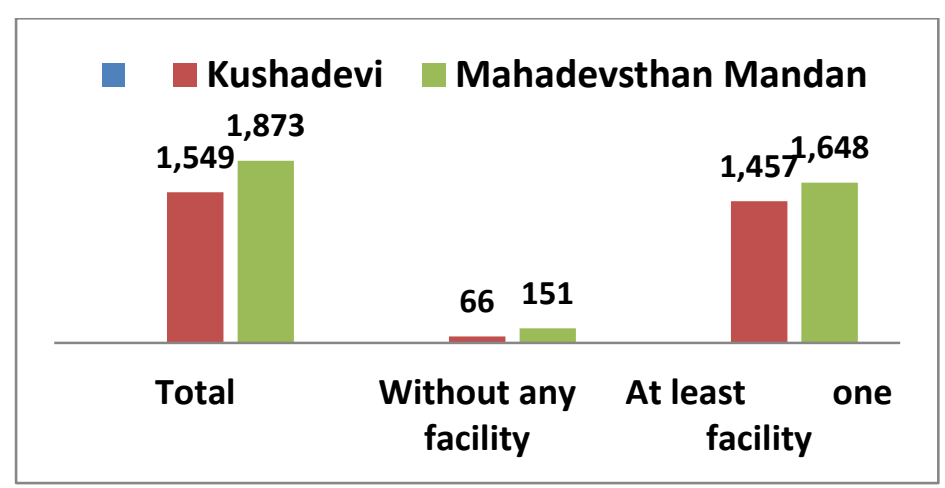

In the same way household having at least one facility (Radio, Television, Cable Television, Computer, Internet, Telephone, Mobile Phone, Motor, Motor- cycle, Cycle, Other vehicle and , Refri-gerator) is 94.06 
percent and 87.99 percent in Kushadev fig - 1 and Mahadevsthan Mandan household respectively (CBS. 2012).

Characteristics of the Farmers: Salient features of the respondent farmers farm size, education level frequency of net use, source of information, are discussed

Table 2Extent of use of different ICT based media by the farmers in receiving information

\begin{tabular}{|l|l|l|l|}
\hline Sl No. & ICT based media & $\begin{array}{l}\text { Percentage of } \\
\text { farmers using(N =98) }\end{array}$ & $\begin{array}{l}\text { Mean Use } \\
\text { (hours/week) }\end{array}$ \\
\hline 1 & $\begin{array}{l}\text { Use of mobile for calling and small text } \\
\text { messaging }\end{array}$ & 37.3 & 0.16 \\
\hline 2 & $\begin{array}{l}\text { Use of internet for national and } \\
\text { international web media }\end{array}$ & 21.3 & 2.65 \\
\hline 3 & Use of internet in smart phones & 2.0 & 0.03 \\
\hline 4 & $\begin{array}{l}\text { Use of internet in private service } \\
\text { provider (cyber cafe/ private shops) }\end{array}$ & 0 & 0 \\
\hline 5 & $\begin{array}{l}\text { Use of internet in friends and family } \\
\text { Use of internet in personal computer } \\
\text { (desktop or laptop) }\end{array}$ & 0 & 0 \\
\hline 6 & 0 & 0 \\
\hline
\end{tabular}

\section{Source Field survey, 2017}

43.7\% of the people were engaged in Agricultural occupation out of which $46.6 \%$ were females. The percentage of people with small farm holdings 0.508 were significantly high with $86.7 \%$ table- 3 .

Table 3Farm Size of the Farmers

\begin{tabular}{|l|l|l|}
\hline Farm size & Frequency & Percentage \\
\hline Up to $0.508 \mathrm{Ha}$ & 85 & 86.7 \\
\hline From $0.508 \mathrm{Ha}$ to $1 \mathrm{Ha}$ & 11 & 11.2 \\
\hline From $1 \mathrm{Ha}$ and above & 2 & 2 \\
\hline
\end{tabular}

Source Field survey, 2017

Table 4Education Level of Farmers

\begin{tabular}{|l|l|l|}
\hline Item & Frequency & Percentage \\
\hline No formal Education & 3 & 3.1 \\
\hline Adult Literacy Education & 13 & 13.3 \\
\hline Primary Education (Class 1 to5) & 24 & 25 \\
\hline Secondary Education* (Class 6 to 10) & 34 & 34.7 \\
\hline Post-Secondary Education** (Above 11) & 23 & 24 \\
\hline
\end{tabular}

Source Field survey, 2017

The survey also showed that about $34.7 \%$ of the farmers had secondary education level table-4 Furthermore, the analysis of the income levels of the farmers engaged in the study indicated that $39.3 \%$ of the farmers interviewed earned less than Nepalese Rupee 280,000 a year. Similarly $27 \%$ of the farmers earned between Nepalese Rupee 280,000-390,000 a year and 33.7\% of the farmers earned above Nepalese Rupee 390,000 a year. An income of around 780,000 per year was observed in Kushdevi VDC. This might be due to the fact that the respondent who possessed more than 20 Ropanis of land were engaged in commercial farming too. Similarly, the lowest income of around 684,000 was observed in Mahadevsthan VDC.

The surveyed VDCs were found to be covered by mobile phone network. The main network operators are Nepal Telecom and Ncell Private Limited. The analysis of the mobile phone indicated that $95.4 \%$ of the farmers possessed mobile. The analysis of the usage of internet by the farmers indicated that $23 \%$ of the 
farmers are internet users while $23 \%$ of farmers had offspring who were internet user (Table-5). Similarly $4 \%$ of the farmers had siblings who use internet while $50 \%$ of the farmers did not use internet or have anyone who would use internet for information access. The table below presents the descriptive analysis of the internet usage by the farmers or the members of their households. The result also indicated that $50 \%$ of the household have an internet user.

Table 5Frequency Distribution of the internet usage by the farmers

\begin{tabular}{|l|l|l|}
\hline Internet User & Frequency & Percent \\
\hline Self & 23 & 23 \\
\hline Offspring & 23 & 23 \\
\hline Siblings & 4 & 4 \\
\hline None & 49 & 50 \\
\hline
\end{tabular}

Source Field survey, 2017

The analysis of the association of the respondents to a farmers' group was done. The analysis indicated that $64.8 \%$ of the respondents were not associated with any farmers' group as such, while $35.2 \%$ indicated that they were associated to a farmers' group. The table below indicates the description of the frequency of famers' group association (Table-6).

Table 6Farmers' group association of the farmers

\begin{tabular}{|l|l|l|}
\hline Farmers' Group Association & Frequency & Percent \\
\hline Yes & 34 & 35.2 \\
\hline No & 64 & 64.8 \\
\hline
\end{tabular}

Source Field survey, 2017

An analysis of the availability of the ICT namely radio, television, mobile, internet and print media for access of agriculture information was done. The result indicated that radio is available to $82.1 \%$ of the respondents for access of agriculture information. Similarly, $67.3 \%$ of the respondents have access to agriculture information through television, while $95.4 \%$ of the farmers possess mobile for accessing agriculture information. Only $4.6 \%$ of the farmers have access to internet for accessing agriculture information. The figure below table- 7 indicates the availability of information and communication technologies among the farmers.

Table 7Information source of the farmers

\begin{tabular}{|l|l|l|}
\hline Information Source & Frequency & Percent \\
\hline Neighbors (farmers) & 36 & 36.7 \\
\hline Farmers' Group / Co-operatives & 08 & 8.2 \\
\hline Trainings/Seminars/ Workshops & 19 & 19.9 \\
\hline Agriculture officers/JTA/ Agro-experts & 28 & 28.6 \\
\hline Others* & 7 & 6.6 \\
\hline
\end{tabular}

(Others*: Newspaper, None taken, self-informed, personal contacts, input distributor, etc).

Source Field survey, 2017

DADO Kavrepalanchowk is a district level Government agency primarily mandated for planning, executing, coordinating and monitoring agricultural programs in the Kavrepalanchowk district for the wellbeing of people. The study investigated the ICT tools used by District Agriculture Development Office, Kavrepalanchowk for agriculture information dissemination. Apart from the usual traditional radio and television programs, usage of mobile for information access by farmers was reported by Senior Agriculture Officer of DADO, Kavrepalanchowk. Lack of basic infrastructure such as year round road and telecom facilities are the main hindrances for disseminating agriculture information as stated by DADO, Kavrepalanchowk. 
There are altogether 6 agriculture service centers and 7 communication centers excluding the DADO office at Dhulikhel. The unreached population is facilitated by agriculture technicians (JTA) for information access. But the resources are inadequate in catering all the farmers of Kavrepalanchowk. Realizing the importance of mobile in information access, DADO, Kavrepalanchowk have launched a toll free number where farmers can connect to get agriculture information. The utility of the toll free number is satisfactory as reported by the officers at DADO, Kavrepalanchowk. But the investigation of the same among the farmers found that they are unaware of the toll free number. Other initiatives taken by the DADO, Kavrepalanchowk are mobile training and horticulture in school. Mobile training is a program where agriculture experts visit to villages where transportation is available. Horticulture in School is a yearly program where selected and interested students are trained on basic horticulture practices.

Given the socio-economic challenges and other criteria, this research also sought to establish the appropriate ICT that can be applied for information dissemination. The establishment of appropriate or effective ICT for information access was studied through the attitude of famers. The effectiveness of the ICT tools such as radio, television, mobile phone, internet and print media was measured in likert scale of 5 where 1 indicated not effective and 5 indicated very effective. Effectiveness of the various ICTs and results are discussed below.

The result also indicated that $42.9 \%$ of the respondents rated radio as little expensive, $29.6 \%$ rated it as not expensive, $21.9 \%$ rated it as moderately expensive, $3.6 \%$ rated it as expensive and $2 \%$ rated it at very expensive. The earlier findings indicated that majority of respondents possessed radio and majority rated it as little expensive or not expensive at all. The figure -2 below represents the frequency description of the effectiveness rating of radio.

Figure 2Effectiveness of Radio

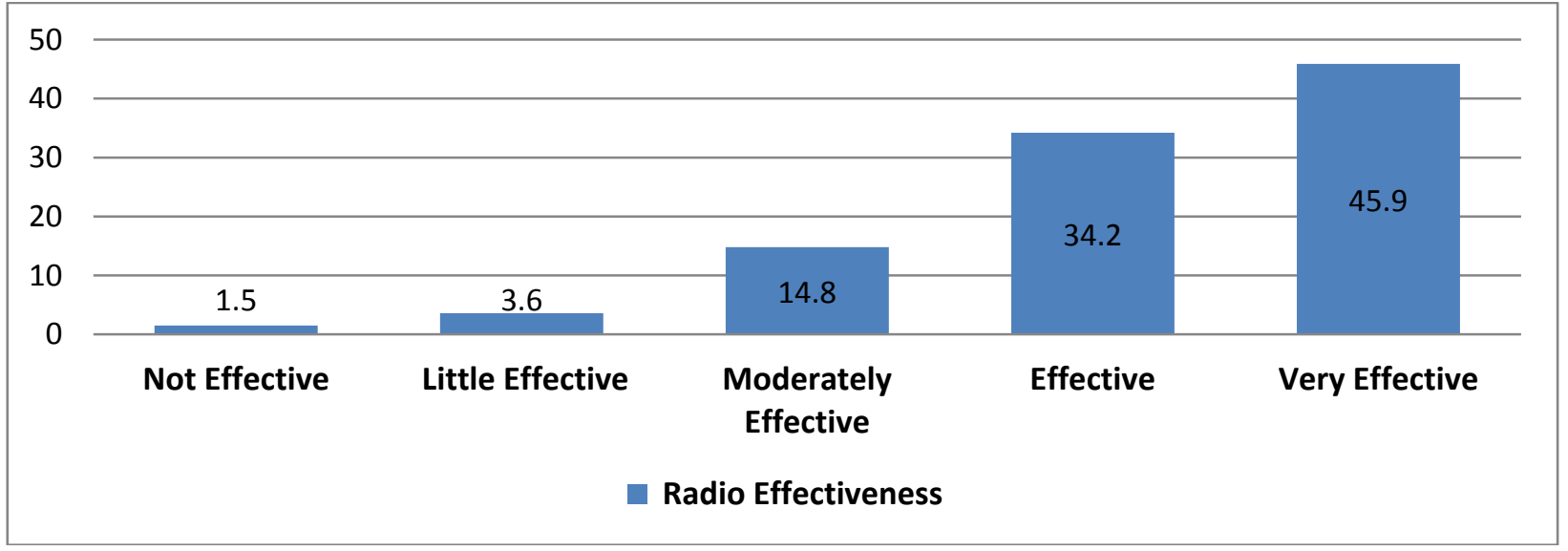

Daily agriculture news broadcasting in Nepal Television is a recent initiative and achievement of AICC. Agriculture television programs have been made more attractive with inclusion of teleserial, agriculture talk program and lesson from agriculture in foreign countries. The effectiveness rating of $\mathrm{TV}$ is presented in figure-3. 
Figure 3Effectiveness of Television

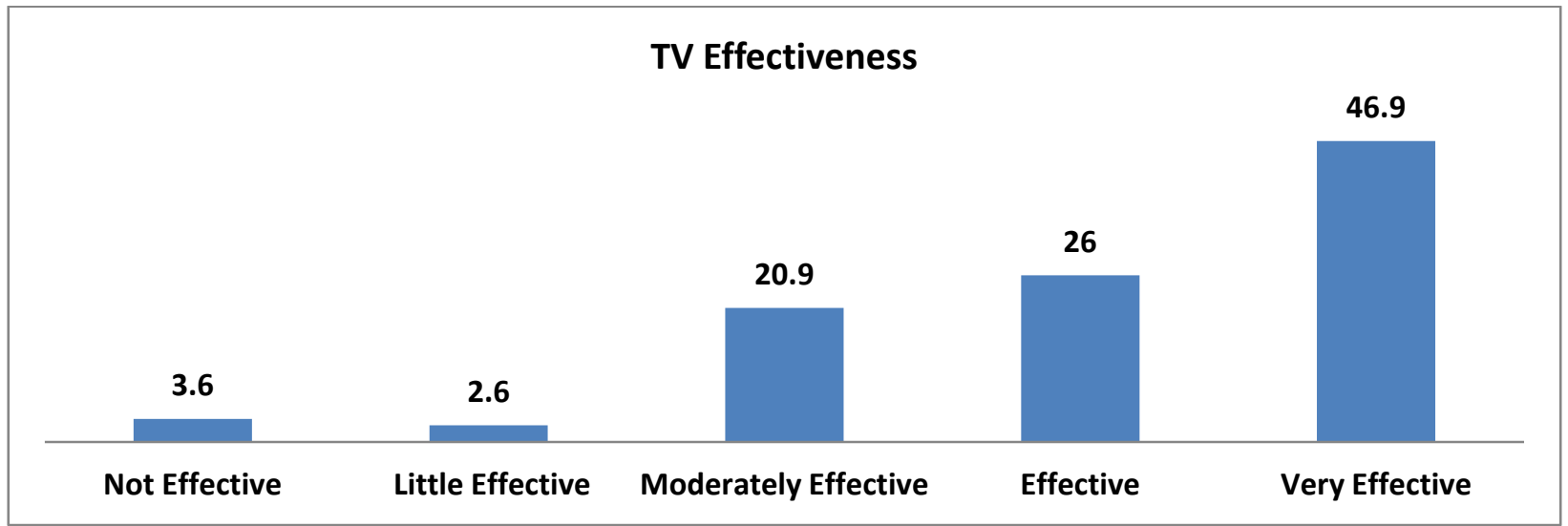

The findings also indicated that majority of the farmers rated telephone as expensive.

The results indicate that $33.7 \%$ of the respondents rated telephone as expensive, $31.1 \%$ rated it as very expensive, $8.7 \%$ rated it as moderately expensive, $25.5 \%$ rated as little expensive and $1 \%$ of the farmers rated it as not expensive. About $55.1 \%$ of the farmers deduced Mobile to be moderately expensive. Majority of the respondents $58.2 \%$ rated internet as very expensive. About $48.5 \%$ of the respondents said that the print media was little expensive. Regarding the effectiveness rating of mobile is presented in figure- 4 .

Figure 4Effectiveness of Mobile

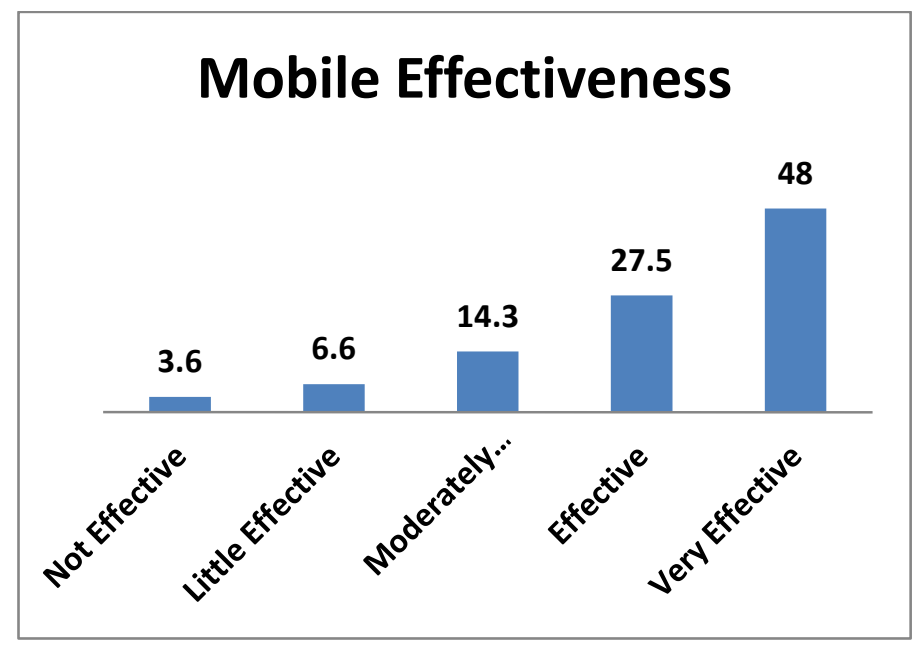

Yield of market derived product Status

Here the productivity of the market derived product tomato, cauliflower, potato and other fresh vegetables is analysed based on the KII and FGD. Members for the FGD are selected with consultation Local Level agriculture Facilitator. Participants are active as local level leader and involved in agriculture as major source of Income. Farmers have diversified their maize based production to high value crops mainly fresh vegetable. It is seen from this discussion that all vegetables production is improved with the use of technology knowledge and market information mainly prices of the commodity to be supplied to the market..

The research also sought to find out the agriculture products that are traded by the farmers. The general agricultural commodities of Kavrepalanchowk district are rice, maize, millet, wheat, barley, potato and others with highest frequency and percentage 40.82 . The table -8 below indicates the agriculture commodities that are sold by the respondents as market driven product. 
Table 8Agriculture commodities sold by the farmers

\begin{tabular}{|l|l|l|}
\hline $\begin{array}{l}\text { Agricultural } \\
\text { Commodities }\end{array}$ & Freq (Yes) & Percent (Yes) \\
\hline Rice & 28 & 28.06 \\
\hline Maize & 43 & 43.88 \\
\hline Millet & 25 & 25.00 \\
\hline Wheat & 17 & 17.86 \\
\hline Barley & 3 & 2.55 \\
\hline Potato & 30 & 30.61 \\
\hline Oil Seeds & 0 & 0.00 \\
\hline Others & $\mathbf{8 0}$ & $\mathbf{4 0 . 8 2}$ \\
\hline
\end{tabular}

(Others*: vegetables and livestock and dairy products)

Source Field survey, 2017

\section{CONCLUSION AND RECOMMENDATIONS}

Information and communication technologies have become popular and effective in India and neighboring countries for agriculture information dissemination. The research indicated that farmers' information needs can be addressed by the combination of push pull technologies such as mobile phones, radio, television and internet. Keeping in mind the availability of the ICT equipment present at farmer's premise needs to be considered to support farmer's information need decision making criteria for ICT implementation. The findings of the research revealed that in the use of ICT-based information media, farmers use cell phone, internet through WebPages, television, Radio and internet through smart phone besides traditional sources like neighbor public agency. As per discussion they use mainly for variety selection, plant protection and market price information for their product. The maximum use is observed in market derived production There is requirement for an integrated approach which would address information needs in using ICT applications. The Government of Nepal has identified Technology is one of the main components Agriculture Development Strategy, Prime Minister Agriculture Modernization Project as well as NARC Vision 2021.Utilization of Television ranked highly suitable followed by mobile phone, and web portals. Literature suggest push and pull mechanism hence a query processing unit where farmers can get solutions to their questions is recommended.

\section{Acknowledgements}

Researcher is thankful to District Agriculture Development office and Prof. Dr. Binayak Rajbhandari Chairmen Himalayan College of Agricultural Science and Technology for encouraging doing this research. The researcher is also thank to Tribhuvan university service commission for the requirement of research work for the upgrading status. Lastly but not least to all respondents who have provided me the information during research period

\section{REFERENCES}

- AED 2017 Annual Programm and Statistics Book, Department of Agriculture, Agriculture Extension Directorate, Lalitpur, Nepal

- CBS 2012, National Population and Housing Census 2011, Central Bureau of Statistics, National Planning Commission, Government of Nepal, Kathmandu, Nepal

- CBS, 2012. Nepal Living standard Survey (NLSS) 3010/11. Central Bureau of Statistics, National Planning Commission, Government of Nepal, Kathmandu, Nepal

- CBS, 2014,Population Monograph of Nepal Volume III (Economic Demography) GON, NPC

- CBS,2013. National Sample Census of Agriculture 2011/12. Central Bureau of Statistics, National Planning Commission, Government of Nepal, Kathmandu, Nepal

- DADO 2017, Annual agriculture development Program and Statistics Book, District Agriculture development Office Kavrepalanchwok (In Nepali)

- Kothari, C.R. (2007), Research methodology methods and technique. New Age international publishers, New Delhi, India 
- Ministry of Information and Communication, Government of Nepal, National Information and Communication Technology Policy, 2015

- MOAC (2007), Nepal Agricultural Extension Strategy (NAES) 2007 (Unofficial Translation From Nepalese). Kathmandu: Ministry of Agriculture and Cooperative.

- MoAD 2016 ABP\&SD, Statistical Information on Nepalese Agriculture 2015/16

- MoAD 2071 M\&E Division, Annual Progress Rreport of MoAD and departments under it

- MoAD, (2017). Features and Status of Nepalese Agriculture. Ministry of Agriculture development, Singhdurbar, Kathmandu, Nepal.

- MoF (2018). Economic Survey, 2017/18, Ministry of Finance, Singh Durbar, Nepal (In Nepali)

- World Bank (2011) e - S ource Book ICT in Agriculture, Connecting Smallholders to Knowledge, Networks, and Institutions Report Number 64605

- Ncell app camp 2014: Mobile application in agriculture, education ... http://www.ashesh.com.np/ncell-app-camp-2014-agriculture-education-and-tourism/7 Nov 2014 ... Among the four sectors included in the Ncell app camp 2014, experts ... Providing a glimpse of current status of agriculture sector of Nepal, ...

- ICT in Agriculture Nepal - Android Apps on Google Play https://play.google.com/store/apps/developer\%3Fid\%3DICT\%2Bin\%2BAgriculture\%2BNepal\%26hl\%3DenIC T in Agriculture Nepal. AICC. Pre-ordered - AICC · ICT in Agriculture Nepal. 1. Free. AgricultureInformation and Communication Center Nepal. 1. Free.

- ICT for Agriculture Becomes the Grand Winner of Ncell App Camp ... http://tech.aakarpost.com/2014/12/ict-for-agriculture-becomes-grand.html11 Dec 2014 ... ICT For Agriculture, grabbed the first prize of Ncell App Camp 2014, securing ... market chain value while also ensuring food security in Nepal.

- Smartphone app helps Nepali farmers - SciDev.Net South Asia http://www.scidev.net/south-asia/agriculture/news/smartphone-app-helps-nepali-farmers.html19 Jan 2015 ... A locally developed smartphone app links Nepali famers to the market ... for Nepalifarmers to link up to the market and to experts at agriculture ...

- 'ICT for Agriculture' wins Ncell App Camp competition http://kathmandupost.ekantipur.com/news/2014-12-12/ict-for-agriculture-wins-ncell-app-campcompetition.html12 Dec 2014 ... 'ICT for Agriculture' wins Ncell App Camp competition ... to see a range of innovative cell phone applications developed by Nepali developers.

- $\quad$ ICT for Agriculture - Creating SMILES http://thenationsmiles.org/ict-for-agriculture/ICT for Agriculture. i.e. IFA (. www.ict4agri.com) is one of the core project of SMILES that has been built in collaboration with US Embassy Nepal. It has SMS and ...

- Agriculture Monitoring to Support Food Security in Nepal - icimod http://apps.geoportal.icimod.org/NepalAgriculture/Agriculture Monitoring to Support Food Security in Nepal. Tools. Close. Zoom In; Zoom Out; Full Screen; Move Left; Move Right; Move; Default ...

- Smart Krishi: A smart Phone App for your Agricultural Needs ... http://techlekh.com/2015/09/25/smart-krishi-smart-phone-app-agricultural-needs/25 Sep 2015 ... It means that the vital information, which plays a great role for changing the conventional methods of farming in Nepal, are available on digital ...

- Nepal| AGRICULTURE BLOG..... https://dineshpanday.wordpress.com/tag/nepal/The "Kisaan Call Centre" initiative by AgriCare, smartphone apps like Krishi Ghar , Smart Krishi,IFA-Krishi Nepal etc. are some examples of smart agriculture ... 